\title{
ANTIMICROBIAL RESISTANCE THERMOTOLERANT Campylobacter spp. AS A FOOD SAFETY ISSUE
}

\section{J. Petrović, I. Stojanov, D. Milanov, M. Kapetanov}

Scientific Veterinary Institute "Novi Sad", 21000 Novi Sad, Rumenacki put 20, Republic of Serbia Corresponding author: jelenap@niv.ns.ac.rs

Review paper

Abstract: Antimicrobial resistance is a daunting public health threat impacting both human and animal health and it is a cause for concern wherever antimicrobial agents are in use. The usage of antimicrobial drugs in food producing animals could results in significant food safety issue - antimicrobial resistance among zoonotic bacteria in these animals. Resistance monitoring program still does not exist in Serbia, so we made a pilot program to screen the situation in our abattoirs. We found similar situation like the one in EU. The resistance to one or more antimicrobial drugs was found in $40.00 \%$ and $75.32 \%$ Campylobacter spp. strains isolated from poultry and pig carcasses, respectively. Fluoroquinolones are anitmicrobial drugs which, beside beta-lactams, are most often used in poultry breeding. Fluoroquinolones are also very important for treatment of some human diseases. We examined relationship between presence of fluoroquinolone resistant C. jejuni in poultry carcasses and fluoroquinolone treatment of poultry. Treatment with one of this antimicrobials - enrofloxacine selects resistant strains in chickens carcasses, $C$. jejuni strains resistant to enrofloxacine were isolated from all livers $(100 \%)$ and $70 \%$ carcasses. The resistant bacteria may then be transmitted to humans through food supply and increase the risk of treatment failures. Resistant zoonotic pathogens in food have to be controlled through a complete, continuous farm-to-fork system

Key words: antimicrobial resistance, Campylobacter, food safety

\section{Introduction}

Most antimicrobials used for the treatment of animals belong to classes that are also used in human medicine (cloxacillin, gentamicin, ampicillin, amoxicillin etc.). The usage of antimicrobial drugs in food producing animals could results in antimicrobial resistance among pathogenic and commensal bacteria in these animals, and the resistant bacteria may then be transmitted to humans through the food chain and increase risk of treatment failures. The consequence of resistance to certain antimicrobials especially fluoroquinolones as well as to $3^{\text {rd }}$ and 
$4^{\text {th }}$ generation cephalosporins and macrolides, are of particular concern, since these are critically important for therapy of human systemic bacterial infections.

Antimicrobial resistance in Campylobacter spp. and other bacteria is an increasing public health problem. Resistant Campylobacter involved in human disease are mostly spread through foods. Contaminated poultry, and pork meat are prominent in this regard. There is a temporal association between the introduction of fluoroquinolones for use in poultry and a substantial rise in the prevalence of quinolone-resistant $C$. jejuni isolated in live poultry, poultry meat and infected humans. Moreover, prior to use in poultry treatment, no resistant strains were reported in humans with no previous exposure to quinolones (Piddock, 1998). A correlation between introduction of fluoroquinolones in treatment of animals and cases of resistant Campylobacter was noticed in Holland and USA (Endtz et al., 1991; Engberg, 2001). Avoparcin was a frequently used growth promoter in poultry until its ban in Denmark in 1995 because of its association with the development and spread of vancomycin-resistant enterococci (in $80 \%$ of poultry). Resistance was also found in humans. After banning avoparcine, cases of vancomicine resistant enteroccoci decreased to 3\% (Prescott et al., 2000).

Since January 2006 the use of all antimicrobial feed additives has been banned within the EU in order to reduce the number of resistant bacteria in farm animals Regulation (EC) No 1831/2003. The effect of this ban on the extent of bacterial antimicrobial resistance both within farm animals, and with regard to human health, however, is as yet unknown (EFSA 2008).

The WHO, FAO, including Codex, and OIE have each (individually or jointly) reviewed the area and provided guidelines, recommendations and lists of clinically important antimicrobials. The latest activity in this area is a Codex Task Force, which aims to assess the risks to human health associated with the presence in food and feed of antimicrobial-resistant organisms, antimicrobial resistance genes and residues of antimicrobials, and to develop risk management advice based on that assessment to reduce such a risk.

\section{Food borne pathogen resistance}

Zoonoses are diseases or infections, which are transmissible from animals to humans. The zoonosis which occur most frequently in the developed world today are food-borne infections caused by Salmonella, Campylobacter, VTEC, Yersinia, Listeria etc.

Although various foods can serve as a source of food borne illness, meat and meat products are important sources of Campylobacter. These two pathogens are most frequently reported causes of zoonotic diseases in EU in 2005, incidence of 38.2-51.6 cases per 100000 population (EFSA, 2005). These bacteria's are reported in all meat producing animals, they are widespread in poultry production in Europe. C. jejuni is frequent commensal in poultry and cattle, and C. coli in swine and poultry. The most common way that humans become infected with 
zoonotic enteric pathogens is through the ingestion of food contaminated with animal feces (contamination usually occurs during processing). Oral medication of large groups of animals is particularly likely to favor emergence of and selection for resistant microorganisms. Also, in animal production conditions exist that facilitate the spread of bacteria, such as high density and/or poor infection control (Stojanov et al., 2006; Stojanov et al., 2009).

Food borne diseases caused by thermopile Campylobacter spp. usually do not demand antimicrobial therapy. When antimicrobials are indicated (immunodeficient patients etc.) for the treatment of campylobacter gastroenteritis, erythromycin or a fluoroquinolone such as ciprofloxacin are the drugs of choice (Smith at al., 1999).

\section{Occurrence of food borne patogen resistance}

Application of antimicrobial drugs in veterinary medicine has been monitored in EU, as well as the resistance of human and zoonotic pathogens (Table 1). Monitoring program has not been applied in Serbia. Therefore, Veterinary Directorate of the Ministry of Agriculture financed three projects of our Institute to screen the situation in Serbia. Performed examinations have found similar situation like in EU. The occurrence of Campylobacter is very frequent in pig and poultry carcasses (Table 2). The occurrence of these bacteria varies depending on the range of factors including the organism, geographical factors, farming and meat production practice. Studies have reported that poultry can become contaminated with Campylobacter at the farm level (Stojanov and Orlić, 2000; Stojanov and Orlić, 2001). These organisms can be transported to the production facility and can contaminate the processing environment and the final product. The influence of farm and production management and is great, since in some abattoirs Campylobacter spp. was found on $11.43 \%$ carcasses, and in other even on $90.00 \%$ carcasses. Similar situation was found in pig abattoirs.

Table 1. Prevalence of resistant Campylobacter spp. strains isolated from food (Mayhofer et al., 2004; MARAN, 2002)

\begin{tabular}{|l|c|c|}
\hline \multirow{2}{*}{ Antimicrobial drug } & Prevalence of resistant strains (\%) \\
\cline { 2 - 3 } & Holland & Austria \\
\hline Fluoroquinolones & 26.9 & 40.7 \\
Tetracyclines & 57.1 & $/$ \\
Streptomycin & 51.3 & 9.7 \\
Ampicillin & 16.8 & 8.6 \\
Erythromycin & 34.5 & 4.0 \\
Gentamicin & 16.8 & 1.5 \\
Chloramphenicol & 0.0 & 0.7 \\
Trimethoprim & $/$ & $/$ \\
Trim/Sulfamethoxazole & 37.0 & $/$ \\
Florfenicol & 0.0 & $/$ \\
Metronidazole & 37.8 & $/$ \\
\hline
\end{tabular}


Table 2. Occurrence of Campylobacter spp. on pig and poultry carcasses (Petrović et al., 2007a; Petrović et al., 2007b)

\begin{tabular}{|c|c|c|c|c|c|c|c|}
\hline Abattoirs & \multicolumn{7}{|c|}{ Occurrence of Campylobacter spp. on carcasses (\%) } \\
\hline Pig abattoirs & A & B & C & D & E & $/$ & $/$ \\
\hline & 3.70 & 22.22 & 14.81 & 5.55 & 1.85 & $/$ & $/$ \\
\hline Poultry abattoirs & A & B & C & D & E & F & G \\
\cline { 2 - 8 } & 40.00 & 5.00 & 8.56 & 6.00 & 34.28 & 2.86 & 5.71 \\
\hline
\end{tabular}

The occurrence of Campylobacter spp. in carcasses varies depending on abattoir. On pig carcasses only $C$. coli were isolated while in poultry $C$. jejuni dominated (89.87\% of isolated Campylobacter strains), $75.32 \%$ Campylobacter strains isolated from poultry samples and $40.00 \%$ strains isolated from pig samples were resistant.

Campylobacter strains isolated from pig samples were resistant to amoxicilline, streptomycine and sulfamethoxazole, while Campylobacter strains from poultry carcasses were resistant mostly to trimethoprime $48.734 \%$, ciprofloxacine $46.20 \%$, and amoxicilline $40.51 \%$ (Table 3). Resistance to erythromycin (7.59\% strains) has special importance because this antimicrobial is the drug of choice for the treatment of human enteric infection caused by $C$. jejuni and C. coli. Strains isolated from poultry showed in the MARAN (2002) report, as well as study, that Campylobacter present the highest rate of resistance to trimethoprime and ciprofloxacine. The resistance patterns of Campylobacter spp. strains found in this study are correlated to the antimicrobial drugs most widely used in veterinary medicine in Serbia (beta-lactam antibiotics and fluoroquinolones).

Table 3. Prevalence of resistant Campylobacter spp. strains isolated from poultry and pig abattoirs (Petrović et al, 2007a,b)

\begin{tabular}{|l|c|c|}
\hline \multirow{2}{*}{ Antimicrobial drug } & \multicolumn{2}{|c|}{ Resistant strains (\% of total isolates) } \\
\cline { 2 - 3 } & Poultry carcasses & Pig carcasses \\
\hline Amoxicillin 25 & 40.51 & 10.00 \\
\hline Cefuroxim 30 & $/$ & $/$ \\
\hline Imipenem 10 & 1.90 & 0.00 \\
\hline Gentamicin 10 & 5.69 & 0.00 \\
\hline Doxycyline 30 & 8.23 & 0.00 \\
\hline Trimethoprim 5 & 48.73 & 0.00 \\
\hline Ciprofloxacin 5 & 46.20 & 0.00 \\
\hline Chloramphenicol 30 & 0.00 & 0.00 \\
\hline Streptomycin 10 & 16.46 & 40.00 \\
\hline Sulfamethoxazole 100 & 8.23 & 30.00 \\
\hline Erythromycin 15 & 7.59 & 0.00 \\
\hline
\end{tabular}


Although the multidrug resistance patterns were different, the high frequency of multidrug resistant Campylobacter spp. strains found in the present study suggests that strict measures have to be taken to ensure proper use of antimicrobials in veterinary medicine in Serbia. Animals and food of animal origin play an important role in the transmission of campylobacteriosis and salmonelosis to humans. So the findings of multidrug resistant Campylobacter spp. strains from domestic animals stressed the importance of epidemiological surveillance and preventive actions that may avoid the dissemination of these strains over animal and human populations.

Based on the performed research it may be concluded that the resistance of food borne pathogens is present in Serbia. It may be considered as an important hazard for human health since a considerable number of isolated pathogens were resistant.

\section{Spread of resistant strains among treated animals}

We have examine relationship between presence of fluoroquinolone resistant $C$. jejuni in poultry carcasses and fluoroquinolone treatment of poultry was examined in the experimental design. Fluoroquinolones are anitmicrobial drugs which, beside beta-lactams, are most often used in poultry breeding. Fluoroquinolones are also very important for treatment of some human diseases.

In experimental design chickens were inoculated with fluoroquinolonesensitive $C$. jejuni strain in the $3^{\text {rd }}$ week of life, when spontaneous infection with campylobacters usually occurs. Treatment with therapeutical dosis of enrofloxacine started after five days. Chickens were slughtered in the poultry abattoir, after the end of withdrawal period (Petrović et al., 2008c). Resistant strains were discovered $24 \mathrm{~h}$ after first therapy were applied in $18.75 \%$ of threated chickens and after $48 \mathrm{~h}$ resistant strains were found in all $100 \%$ of chickens. Rate of resistant strains in total population of campylobacters were extremly high $70-100 \%$ (Petrović et al., 2008c). It is considered that resistant strains appears in small number of chickens and then they are spread in whole population by horisontal transmition. Fluoroquinolone therapy dicrease number of all intestinal bacterias not only sensitive campylobacters but also competitive microflora so resistant strains easiliy become dominant. Treatment with enrofloxacine selects resistant strains in chickens carcasses, $C$. jejuni strains resistant to enrofloxacine were isolated from all livers (100\%) and 70\% carcasses (Petrović et al., 2008c). Prevalence of campylobacters in flock and concentration of this bacterias in caeca in combination with higienic conditions in meat processing plant makes strong influence on number of campylobacters on carcasse and human exposusre from poultry meat (Petrović et al., 2007; Petrović et al., 2008a; Petrović et al., 2008c; Petrović et al., 2009). 


\title{
Control strategies
}

In order to continue decreasing the number of resistant pathogens, partners from the farming, veterinary, medical and public health communities will need to work together to prevent the misuse and overuse of antimicrobials. Besides preventive and hygiene-sanitary measures, the problem of pathogen resistance demands introducing system of surveillance and applying control system in the primary production. This can provide control of distribution, application of antimicrobial drugs and carrying out adequate resistance monitoring program (Petrović et al., 2007a; Petrović et al., 2007b; Petrović et al., 2007c; Petrović et al., 2009). EU regulates the conditions and paths of monitoring through Directive 2003/99EC, also in 2001 WHO published Global Strategy for Limiting Antimicrobial Resistance where the recommendations and instructions for patients, doctors and drug sellers are given.

\section{Conclusion}

Zoonotic pathogens in food have to be controlled through a complete, continuous farm-to-fork system. Application of prophylactic and zoosanitary measures in farm breeding, slaughtering, processing of meat and safe disposal of animal wastes may considerably reduce risk from the incidence of zoonotic pathogens.

\section{Acknowledgment} 2014).

Project MNTR Government of Serbia no. TR31071 for the period (2011-

\section{Rezistencija termotolerantnih Campylobacter vrsta bakterija prema antimikrobnim lekovima kao pitanje bezbednosti hrane}

\author{
J. Petrović, I. Stojanov, D. Milanov, M. Kapetanov
}

\section{Rezime}

Rezistencija prema antimikrobnim lekovima je značajna pretnja javnom zdravlju koja utiče kako na zdravlje ljudi tako i na zdravlje životinja i mora se imati u vidu pri svakoj upotrebi ovih lekova. Upotreba antimikrobnih lekova kod životinja namenjenih za proizvodnju hrane može predstavljati važno pitanje bezbednosti hrane jer dovodi do pojave rezistencije zoonotskih bakterija kod životinja. Program monitoringa rezistencije još uvek nije uveden u Srbiji, tako da je 
naš Institut napravio pilot program da bi se stekao uvid u situaciju u našim klanicama. Ustanovljena je situacija slična onoj u Evropskoj Uniji. Rezistencija prema jednom ili više antimikrobnih lekova je ustanovljena kod 40,00 i 75,32\% Campylobacter sojeva izolovanih sa trupova živine i svinja. Fluorohinoloni su antimikrobni lekovi koji se pored beta-laktama najčešće koriste u uzgoju živine i svinja kod nas, oni su takođe veoma značajni za lečenje pojedinih oboljenja ljudi. Ispitana je veza između prisustva sojeva $C$. jejuni rezistentnih prema fluorohinolonima na trupovima živine i lečenja živine ovim lekovima. Lečenje jednim od lekova iz ove grupe - enrofloksacinom je dovelo do selekcije rezistentnih sojeva na trupovima živine, rezistentni sojevei $C$. jejuni su izolovani iz svih jetri (100\%) i sa $70 \%$ trupova.

Rezistentni sojevi zoonotskih bakterija mogu putem lanca hrane biti prenešeni do čoveka i povećati rizik od neuspelog lečenja. Kontrola ovih sojeva je moguća jedino kroz kompletan i kontinuiran nadzor od farme do trpeze.

\section{References}

EFSA (2005): EFSA Report of the EFSA Panel on Biological Hazards on the request from the Commission related to Campylobacter in animals and foodstuffs. Annex to The EFSA Journal 173, 1-105.

EFSA (2008): Food borne antimicrobial resistance as a biological hazard. Draft scientific opinion of the panel on biological hazards (Question No EFSA-Q-2007089). Draft endorsed on 6 March 2008.

ENDTZ H., RUIJS G., VAN KLINGEREN B., JANSEN W., VAN DER REYDEN T., MOUTON R. (1991): Quinolone resistance in Campylobacter isolated from man and poultry following the introduction of fluoroquinolones in veterinary medicine. J Antimicrob Chemother. 27, 2, 199-208.

ENGBERG J., AARESTRUP F., TAYLOR D., GERNER-SMIDT P., NACHAMKIN I. (2001): Quinolone and macrolide resistance in Campylobacter jejuni and $C$. coli: resistance mechanisms and trends in human isolates. Emergening Infectious Deseases. 7, 1, 24-34.

MARAN (2002): Monitoring of antimicrobial resistance and antibiotic usage in animals in the Netherlands in 2002.

MAYRHOFER S., PAULSEN P., SMULDERS F., HILBERT F. (2004): Antimicrobial resistance profile of five major food-borne pathogens isolated from beef,pork and poultry. Int J of Food Microbiol. 87, 1, 23-29.

PIDDOCK L. (1998): Quinolone-resistant Campylobacetr in the United Kingdom. Use of quinolones in food animals and potential impact on human health. Report and Proceedings of a WHO Meeting.Geneva, Switzerland, 2-5 June, 189-198

PETROVIĆ J., BALTIĆ M., KLJAJIĆ R., KAPETANOV M. (2007a): Rezistencija zoonotskih patogena koji poticu iz mesa živine prema antimikrobnim lekovima. Tehnologija mesa, 301, 147-152.

PETROVIĆ J., KARABASIL N., BALTIĆ M., KLJAJIĆ R., DIMITRIJEVIĆ M., KRASIĆ J. (2007b): Ispitivanje osetljivosti na razlicite antimikrobne lekove sojeva 
Salmonella izolovanih u lancu proizvodnje mesa živine i svinja. 1. Međunarodni kongres Tehnologija, kvalitet i bezbednost hrane. I Simpozijum biotehnologije i mikrobiologije hrane, 13-15.10. 2007. godine, Novi Sad, 105-111.

PETROVIĆ J., BALTIĆ M., KLJAJIĆ R., KAPETANOV M. (2007c): Rezistencija zoonotskih patogena koji potiču iz mesa živine prema antimikrobnim lekovima.Tehnologija mesa, 49, 3-4, 147-152.

PETROVIĆ J., PETROVIĆ T., KOVAČEVIĆ M. (2008a): Food safety trends: antimicrobial resistance in food borne pathogens, viruses in food and safe disposal of animal wastes. The second joint PSU-UNS international conference on BioScience: Food, agriculture and the environment, 22-24.06.2008, Novi Sad, Serbia, Proceedings, 36-44.

PETROVIĆ J., MILANOV D., RATAJAC R. (2008b): Savremeni trendovi u bezbednosti hrane: Rezistencija zoonotskih patogena prema antimikrobnim lekovima. Veterinarski glasnik 62, 5-6, 257-406.

PETROVIĆ J., BALTIĆ M., KARABASIL N., MILANOV D. (2008c): Fluoroquinolone resistance of $C$.jejuni isolated from carcasses of broilers treated with enrofloxacine. Abstract Book, XII International Congress of Bacteriology and Applied Microbiology, 5-9.08.2008, Istanbul, 262.

PETROVIĆ J., STEFANOVIĆ S., BALTIĆ M., RATAJAC R., RACKOV O. (2009): Primena enorfloksacina u živinarstvu kao potencijalni rizik za bezbednost hrane- rezidue veterinarskih lekova u jestivim tkivima. Tehnologija mesa, 50, 34,189-194.

PRESCOTT J., BAGGOT J., WALKER R. (2000): Antimicrobial therapy in veterinary medicine. Third Edition. Iowa State University Press/ Ames.

STOJANOV I., ORLIĆ D. (2000): Infections in parental flock and eggs on Campylobacter and Salmonella strains. Zbornik Matice srpske za prirodne nauke, 101, 101-107.

STOJANOV I., ORLIĆ D. (2001): Types of Campylobaster strains in laying hens with or without diarrhoea. Zbornik Matice srpske za prirodne nauke, 98, 61-66.

STOJANOV I., PRODANOV J., KAPETANOV M., STOJANOVIĆ D., PETROVIĆ J. (2006): Ekologija Campylobacter spp. i njihov značaj za zdravstveno bezbednu hranu (Ecology of Campylobacter spp. and their importance for food safety). Zdravstveno bezbedna hrana/IV Međunarodna Eko-konferencija, 20-23.09.2006. godine, Novi Sad; Zbornik radova, 121-126.

STOJANOV I., PETROVIĆ J., RATAJAC R., JAKŠIĆ S., ŽIVKOV-BALOŠ M., STOJANOVIĆ D. (2009): Influence of immune stress factors on the presence and shedding of Campylobacter jejuni in poultry. Biotechnology in Animal Husbandry, 25, 5-6, 1123-9.

SMITH K., BESSER J., HEDBERG C., LEANO F., BENDER J., WICKLUND J., JOHNSON B. (1999): Quinolone-resistant Campylobacter jejuni infections in Minnesota, 1992-1998. Investigation Team. N Engl J Med, 340, 20, 1525-1532. 